УДК 330.341 .12

JEL I2

DOI: $10.17213 / 2312-6469-2020-5-61-66$

\title{
DEVELOPMENT OF A SYSTEM OF INDICATORS CHARACTERIZING INNOVATION AND INNOVATIVE ACTIVITY IN TECHNOPARKS
}

\section{(C) Roza O. Shahverdiyeva 2020}

\author{
Institute of Information Technology of Azerbaijan National Academy \\ of Sciences, Baku, Azerbaijan
}

The article is devoted to the development of a system of indicators characterizing innovation and innovative activity in technoparks. The role, importance and features of activity of technopark structures in economic development were analyzed. The current situation in Azerbaijan on international innovation and economic indices was analyzed. Features of the system of monitoring the innovative situation in technoparks were studied, a system of indicators characterizing innovation and innovative activity was developed. Prospects for the application of the IV Industrial Revolution in increasing the efficiency of technology parks are shown. Comprehensive recommendations and suggestions were given on the development of a system of indicators characterizing innovation and innovative activity in technoparks.

Keywords: information economy, innovation activity, technopark, database of indicators, IV Industrial revolution.

\section{Introduction}

At present, most advanced countries are operating in accordance with the innovative economic development model. New development concepts and strategies are being developed to ensure the sustainability and effectiveness of economic reforms in this area. One of the main goals of the Strategic Road Maps adopted in our country for the main sectors of the economy [1] is to improve the ICT infrastructure for the digitization of the economy and increase the potential of the country's ICT industry. One of the main goals in building an innovation-oriented, knowledge-based economic system in the Azerbaijan economy, formed in accordance with the challenges of the IV Industrial Revolution [2], is to bring high-quality and competitive information technology products to international and local markets, create clusters and high-tech parks. The development of a system of indicators characterizing innovation and innovative activity in technology parks is one of the most necessary and urgent issues for the modern era.

The purpose of the scientific research on the development of a system of indicators characterizing innovation and innovative activity in technology parks is to determine the conceptual basis of the monitoring system characterizing the 
innovative situation based on the analysis of the current state of international indices of innovative economic development in Azerbaijan. The purpose of the research is to determine the prospects for the application of the technological components of the IV Industrial Revolution in the activities of technopark structures.

The role, importance and activity features of technoparks in economic development

Technoparks play an important role in the economic development of any country. Because the basis of the infrastructure of the information and knowledge economy is technopark structures [3-5]. They are scientifically innovative enterprises that carry out processes related to the development of scientific and technical innovations and their application in production. The essence of the formation of such structures is to stimulate economic development both in the country and in the region, to accelerate the transition from an industrial society to an information and knowledge society, to achieve easier and faster commercialization of scientific ideas and knowledge.

Depending on the purpose of creation, technoparks perform certain functions. The main features of the technopark structures are: their innovative nature; maximum convergence of science, education, production and commerce; application of various incentive mechanisms and regimes; development of intellectual products, rapid implementation of research results, transfer of innovative technologies, etc.

Technoparks have various organizational, legal and functional forms. They have a specialization in certain areas, depending on the goals of formation and the nature of the activity. Based on the information obtained from the official portal of the International Association of Scientific Parks, the specialization of such structures by areas of activity is shown in Fig. 1 [6].

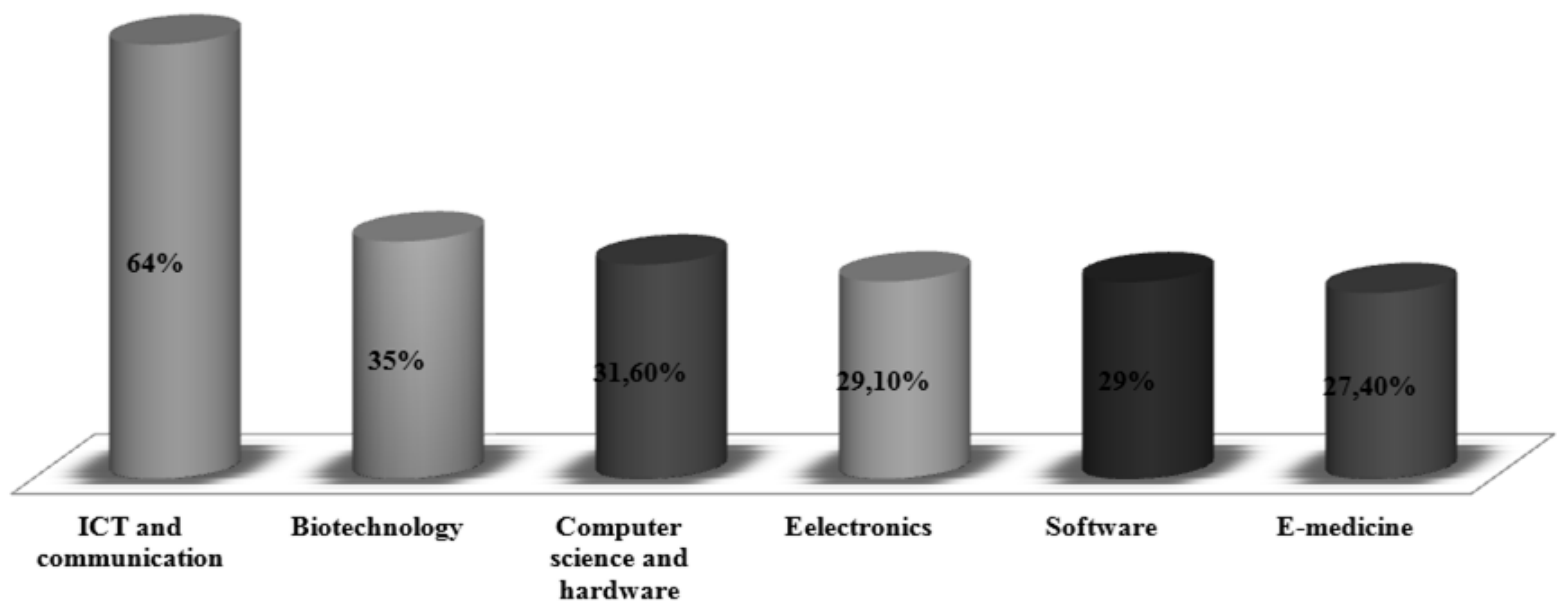

Fig. 1. Specialization of technopark structures by areas of activity 
The model of activity of modern science and technology parks, taking into account the trends of the IV Industrial Revolution, may consist of the following components [7, 8]: 1) additive technology and structures, 2) adaptive technology and structures, 3) increasing the role of the human factor, 4) innovative products, taking into account the development prospects of services, 5) customer-oriented logistics, e-commerce, blockchain technology and marketing, 6) flexible management structure, 7) application of robotics, artificial intelligence and intelligent systems, 8) modern ICT, The Internet of Things IoT, cyber-physical systems, grid, cloud, other technologies, etc.

\section{Analysis of the current situation in Azerbaijan on international inno- vation and economic indices}

Recently, the annual reports of international organizations determine the economic and innovative indices of the world in various fields. In 2019, the Global Innovation Index assessed the effectiveness of innovation in about 130 countries [9]. In that report, Azerbaijan ranked 84th with a score of 30.21 on a scale of $0-100$. The institutions of Azerbaijan are ranked 59th with 64.5 points, human capital and research is ranked 106th with 17.0 points, infrastructure is ranked 70th with 45.3 points, market improvement level is ranked 31st with 56.5 points, business improvement level - 24.5 points in 103rd place, knowledge and technology results - 14.9 points in 101st place, creative activities results in 22.8 points in 84th place.

In the Doing Business - 2019 report, Azerbaijan ranked 25th out of 190 countries in terms of ease of doing business and scored 78.64 points [10]. In that report, the assessment of 190 countries was calculated on the basis of 10 indicators.

Analysis of the Global Entrepreneurship Index's ranking of 137 countries for 2018 shows that in 2018, Azerbaijan scored 30.5 points, ranking 62nd in the list of 137 countries in that report [11]. According to the Global Entrepreneurship Index of Azerbaijan, the results of the assessment for the structural elements of the relations sub-index, sub-capacity sub-index and development subindex were as follows: 1) risk capital 19\%; 2) internationalization $-44 \%$; 3 ) high growth and development $-72 \%$; 4) process innovation $-16 \%$; 5) product innovation $-84 \%$; 6) competitiveness - 25\%; 7) human capital $-56 \%$; 8) mastering technology $-41 \%$; 9) startup opportunity - 23\%; 10) cultural support $-20 \%$; 11) networks $-19 \%$; 12) risk probability $-14 \%$; 13) startup skills $19 \%$; 14) the possibility of a favorable environment $-19 \%$.

The analysis of these complex innovations and international innovation indicators once again confirms that the country has untapped resources. Identifying ways to use them effectively can increase the efficiency of technopark structures.

Features of the innovative situation monitoring system in technoparks

As a result of research and analysis, it was proposed to establish an appropriate monitoring system to assist in the creation, organization and 
management of innovations in the country, as well as the effective management of the innovative situation [12-15]. The monitoring system is in principle part of the system of regulation and forecasting of economic development. It faces many issues to be resolved.

Thus, the organization of operational control over the situation with innovations, timely detection of problems in the implementation of the national innovation system and identifying the nature of these problems, their causes, as well as ways to overcome them, assessing innovation potential, studying trends in innovation activity, influencing factors It is important to determine the degree of impact and take preventive measures as a result. The indicators included in the proposed system should be grouped in several directions and based on them, complex integrative indicators should be developed.

The processes of creation, organization and management of innovations in technopark structures, as well as the central and sub-indicator bases of the proposed monitoring system in connection with the innovative situation and the relationship between them can be shown in figure 2 .

Prospects for the application of the IV Industrial Revolution in improving the efficiency of technopark structures

One of the necessary issues is to study the prospects of the application of the IV Industrial Revolution in accelerating the process of forming an economy based on knowledge and information. The realization and application of the elements of the IV Industrial Revolution in technoparks is one of the urgent issues.

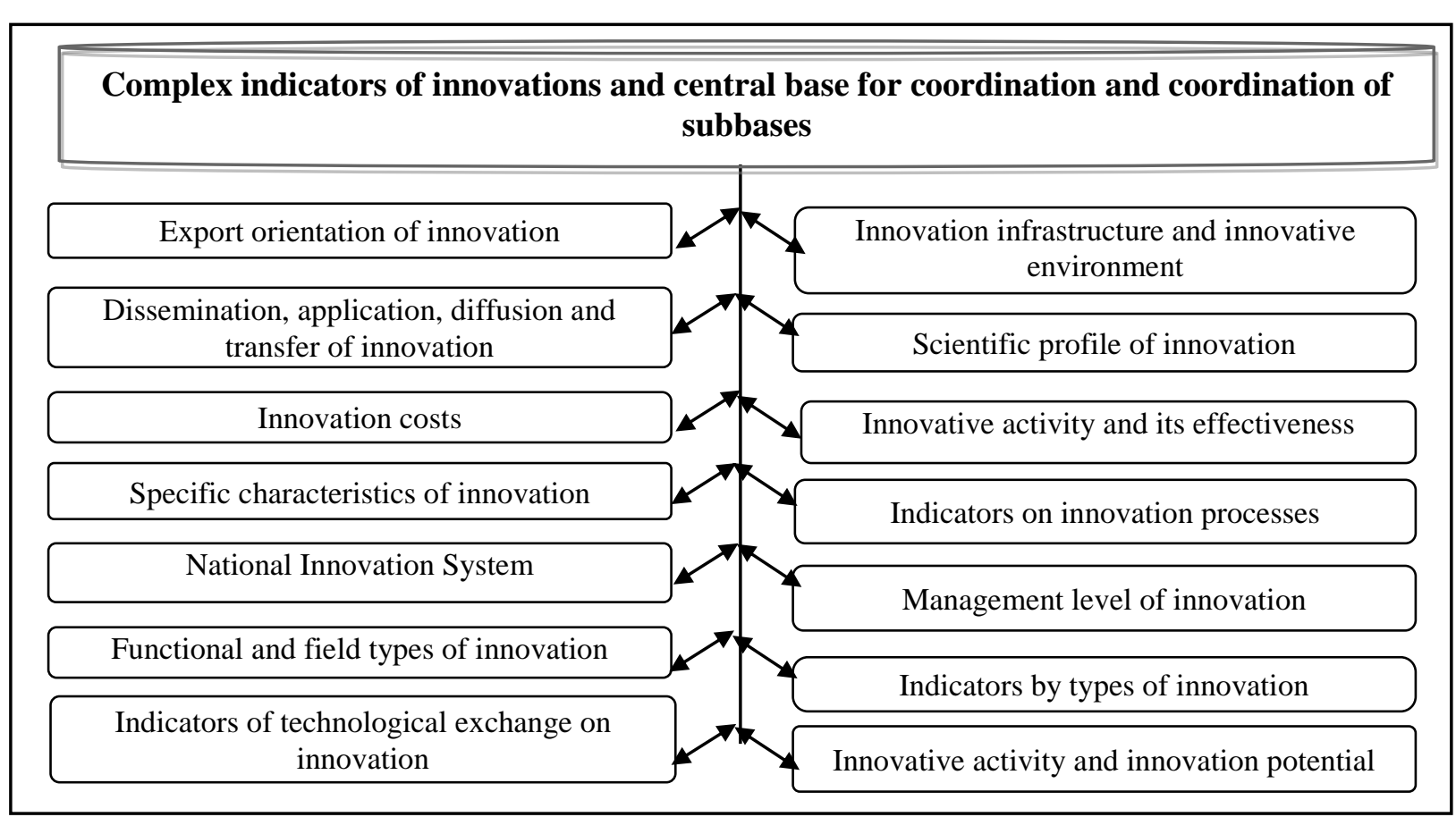

Fig. 2. Basic indicators base of the monitoring system characterizing the innovative situation in the technopark structures In addition, the central base carries out the interaction and coordination of bases 
The main Internet and information technologies based on the IV Industrial Revolution in various fields of application include: implant technology, new visual interface, portable Internet (clothing Internet), Internet of Things (IoT), "smart" home, "digital" 3D edition in the field of man, mobile supercomputer, "smart" city, Big Data technologies, unmanned vehicles, artificial intelligence, robotics, cryptocurrency technologies, production, education, medical sphere and consumer goods $[2,16,17]$.

Research shows that the innovations brought and to be brought by the Fourth Industrial Revolution, the emergence of new revolutions in modern times, create promising opportunities for its transition. Thus, how the structural elements of innovative technologies existing in the IV Industrial Revolution interact with each other, function and further improve the relationship between these elements in the near future can lead to the formation of a new V Industrial Revolution. Favorable conditions are created for the sustainable, uninterrupted development of new technologies. For this reason, ample opportunities are being created for the formation of the next V Industrial Revolution.

\section{Conclusion}

It is necessary to create technoparks in the formation of an economy based on knowledge and information. Due to the importance of technoparks in economic development, one of the urgent issues is to identify current and future directions to increase its efficiency. Analyzes have shown that additional investment in the non-oil sector through technoparks is becoming an important driver of a more competitive economy.

Azerbaijan's rating on international innovation and economic indices has been studied. A system of indicators of the monitoring system characterizing the innovative situation in technoparks has been proposed. Prospects for the application of the IV Industrial Revolution in increasing the efficiency of the technopark structures are shown. Comprehensive recommendations and proposals were given to increase the efficiency of innovative structures and enterprises formed in this direction.

\section{References}

1. Strategic Roadmaps for the National Economy and Main Economic Sectors. Baku, 2016. December 6th. http://www.president.az.

2. Centre for the Fourth Industrial Revolution Network. 2019. P. 24. https://weforum.ent.box.com/v/C4IR-Brochure.

3. Khanmirzaee S. P., Jafari M., Akhavan P. A study on the role of science and technology parks in development of knowledge-based economy// World Journal of Entrepreneurship Management and Sustainable Development. 2018. Vol. 14. Issue 1. P. 74-85.

4. Hobbs K.G., Link A.N., Scott J.T. Science and technology parks: An annotated and analytical literature review// Int. journal of technology transfer. 2017. Vol. 42. No. 4. P. 957-976.

5. Lecluyse L., Knockaert M., Spithoven A. The contribution of science parks: a literature review and future research agenda// Journal of Technology Transfer. 2019. Vol. 44. Issue 2. P. 559-595. 
6. International Association of Science Parks and Areas of Innovation. 2019. http://www.iasp.ws.

7. European Commission. Factories of the future multi-annual roadmap for the contractual PPP under Horizon, 2020. Prepared by: European Factories of the Future Research Association (EFFRA) a Manufuture İnitiative, http://www.ec.europe.eu European Technology Platform (ETP) for Future Manufacturing Technologies: ManuFuture. P. 136. http://www.manufuture.org/manufacturing.

8. Aliyev A.G., Shahverdiyeva R.O. Perspective directions of development of innovative structures on the basis of modern technologies// International Journal of Engineering and Manufacturing (IJEM). 2018. Vol. 8. No. 4. P. 1-12.

9. Global Innovation Index-2019, 451p. http://www.globalinnovationindex.org/Home.

10. Doing Business-2019, 311 p. http://www.doingbusiness.org.

11. Zoltán J. Ács, László Szerb, Ainsley Lloyd. The Global Entrepreneurship Index - 2018. The Global Entrepreneurship and Development Institute. 89 p. http://www.thegedi.org/wpcontent/uploads/dlm_uploads/2017/11/GEI-2018-1.pdf.

12. European Innovation Scoreboards (EIS) - 2019 project for the European Commission. P. 39. https://ec.europa.eu

13. Shahverdiyeva R.O. Perspective directions of increasing the efficiency of the activity of innovation structures// Problems of İnformation Society. 2020. № 1. P. 103-118.

14. Dziallas M., Blind K. Innovation indicators throughout the innovation process: An extensive literature analysis// Journal of technovation. 2019. Vol. 80-81. P. 3-29.

15. Аккужин Ф.Р. Проблемы оценки инновационной деятельности технопарков // Экономика и социум. 2019. № 12 (67). С. 170-174.

16. Skobelev P.O., Borovik S.Yu. On the way from industry 4.0 to industry 5.0: from digital manufacturing to digital society// International scientific journal "industry 4.0". 2017. No. 6. P. 307-311.

17. Yang H., Kumara S., Bukkapatnam S., et al. The Internet of Things for smart manufacturing: A review. IISE Transactions. 2019. Vol. 51. No. 11. P. 1190-1216.

Шахвердиева Роза Ордухан кызы - научный сотрудник Института Информационных Технологий НАНА Азербайджана, г. Баку, Азербайджан.

Shahverdiyeva Roza Or. - research fellow, Institute of Information Technologies of ANAS, Baku, Azerbaijan.

Азербайджан, г. Баку, ул. Суверенитета, 10 10, Suvereniteta str., Baku, Azerbaijan e-mail: shahverdiyevar@gmail.com 